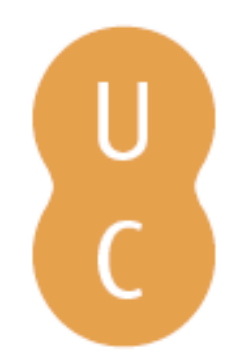

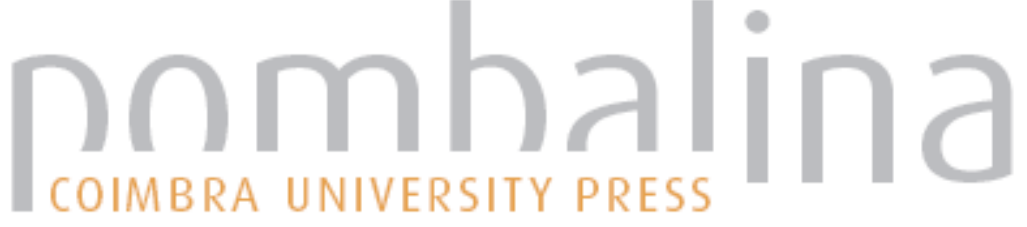

\section{Vestígios gregos em terras brasileiras}

Autor(es): Brandão, Vanessa Ribeiro

Publicado por: Centro de Estudos Clássicos e Humanísticos da Universidade de

URL

persistente: URI:http://hdl.handle.net/10316.2/30170

DOI: $\quad$ DOI:http://dx.doi.org/10.14195/978-989-721-038-9_7

Accessed : $\quad$ 26-Apr-2023 13:44:59

A navegação consulta e descarregamento dos títulos inseridos nas Bibliotecas Digitais UC Digitalis, UC Pombalina e UC Impactum, pressupõem a aceitação plena e sem reservas dos Termos e Condições de Uso destas Bibliotecas Digitais, disponíveis em https://digitalis.uc.pt/pt-pt/termos.

Conforme exposto nos referidos Termos e Condições de Uso, o descarregamento de títulos de acesso restrito requer uma licença válida de autorização devendo o utilizador aceder ao(s) documento(s) a partir de um endereço de IP da instituição detentora da supramencionada licença.

Ao utilizador é apenas permitido o descarregamento para uso pessoal, pelo que o emprego do(s) título(s) descarregado(s) para outro fim, designadamente comercial, carece de autorização do respetivo autor ou editor da obra.

Na medida em que todas as obras da UC Digitalis se encontram protegidas pelo Código do Direito de Autor e Direitos Conexos e demais legislação aplicável, toda a cópia, parcial ou total, deste documento, nos casos em que é legalmente admitida, deverá conter ou fazer-se acompanhar por este aviso.

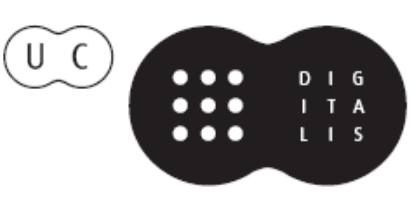




\section{De ayer a hoy}

\section{Influencias clásicas en la literatura}

\section{Aurora López, Andrés Pociña, Maria de Fátima Silva (coords.)}




\title{
VESTÍGIOS GREGOS EM TERRAS BRASILEIRAS
}

\author{
Vanessa Ribeiro Brandẽo \\ Universidade Federal de Minas Gerais
}

\begin{abstract}
O presente trabalho tem por objetivo observar e estudar vestígios da literatura clássica na obra Auto da Compadecida, do escritor brasileiro Ariano Suassuna. Será estudada, primeiramente, a semelhança entre elementos do auto e do teatro grego. A seguir, serão evidenciadas e estudadas a astúcia e a habilidade de convencimento do personagem João Grilo e então comparadas às de Odisseu, herói grego reconhecido por sua esperteza. Ao longo da análise, será verificado se também seria possível comparar esses traços marcantes da personalidade de João Grilo com o comportamento dos sátiros, seres mitológicos e burlescos reconhecidos por sua capacidade de enganar e trapacear.
\end{abstract}

O presente trabalho tem por objetivo observar e estudar vestígios da literatura clássica grega na obra Auto da Compadecida, do escritor brasileiro Ariano Suassuna. É uma peça em três atos que conta a história de João Grilo e seu amigo Chicó, dois homens pobres que trabalham para o mesquinho padeiro e sua esposa. São personagens cômicos: Chicó, pela sua ingenuidade; João pela astúcia de usar a avareza e a ambição dos ricos da cidade contra eles mesmos. A personagem mente e engana cada um deles a fim de garantir a comida e o conforto que a estrutura social daquele lugar não the permite. Ao longo da trama, encontra-se um personagem-tipo, o palhaço, que tem função de narrador e diretor da peça. Ele explicita as rubricas e norteia os atores na construção da cena.

Os dois primeiros atos narram como João Grilo e Chicó enganam o padre, o bispo, os patrões e o cangaceiro Severino, que mata todos esses personagens no final do segundo ato, exceto Chicó. Severino também acaba morrendo por acreditar na mentira dos dois trapaceiros. No terceiro ato, acontece o julgamento das personagens por Jesus, chamado na peça de "Manuel"; pelo diabo, chamado de "Encourado" por estar representado conforme o imaginário nordestino; e logo depois, também pela Compadecida, que é Maria, mãe de Manuel, que, a pedido de João Grilo, intercede por ele.

A religiosidade, o cangaço e a cultura nordestina evidenciados na obra estão diretamente relacionados a um movimento organizado por alguns artistas na década de 70, no Recife, chamado de "Movimento Armorial". Ele, segundo a pesquisadora Idelette Santos, veio a se tornar, "um dos pólos da criação artística do Nordeste da época", com o intuito de provocar questionamentos como a denominação e a definição de cultura popular ${ }^{1}$.

\footnotetext{
${ }^{1}$ Santos, Em demanda da poética popular: Ariano Suassuna e o Movimento Armorial, p.13-14.
} 
Dessa forma, o questionamento sobre o conceito de "popular" se faz importante. Conforme as teorias de Pierre Bourdieu no campo da ciência social citadas por Idelette Santos², o "popular" apresenta três características principais: relaciona-se à manifestação do povo, à margem do que seria o "modelo culto", apresentando um caráter socioeconômico; substitui a voz do povo, relacionado ao que chamamos de folclore; e seduz o povo, de forma a ser aquilo admirado por ele. Tomando como base tais conceitos, a peça representa o popular tanto pelas personagens como pelo enredo.

A pesquisadora também afirma que o movimento propunha uma revitalização da arte nacional por meio de um resgate de três formas artísticas distintas, que seriam os Romanceiros Populares do Nordeste (Literatura de Cordel) junto da música de viola, rabeca ou pífano que os acompanham e a xilogravura que ilustra suas capas. Percebe-se isso facilmente pelo enredo, que se baseia em folhetos nordestinos, apontados também por ela e diversos teóricos, inclusive o autor da obra. São eles: O enterro do cachorro, de Leandro Gomes de Barros, História do cavalo que defecava dinheiro, anônimo, O castigo da soberba, de Anselmo Vieira de Souza, e A peleja da alma, de Silvino Pirauá de Lima.

A inspiração das peças em mitos e histórias já conhecidas e aceitas por um povo acontece desde a época clássica. Além disso, a manifestação da religiosidade popular brasileira (sobretudo nordestina) alude aos festivais quando eram representadas peças de teatro em honra ao deus Dioniso. Também o caráter educativo do gênero "auto", uma modalidade teatral de grande relevância didaticopedagógica que usa a alegoria para reafirmar os valores e dogmas cristãos impostos pela Igreja, inaugurado na Idade Média, pode aludir às teorias que corroboram que a tragédia teria fins educativos. Schiller, em sua Teoria da tragédia (1991, p.14), afirma que se crê que a tragédia presta "um relevante serviço quando, em lugar do frívolo propósito de deleitar, se lhes imputa um fim moral”. Na introdução dessa obra, Anatol Rosenfeld afirma que a tragédia

proporciona ao espectador a possibilidade de experimentar, livremente, lucidamente, o cerne na existência moral em todos os seus conflitos, em todas as suas virtualidades negativas e positivas (1991, p.11).

Ainda que a tragédia e o auto apresentem fins moralizantes, na obra de Suassuna as personagens, diferentemente da tragédia e como se espera de figuras cômicas, não são nobres, mas "populares", figuras que representam o povo. O público se reconhece e reconhece as pessoas que participam de seu

\footnotetext{
${ }^{2}$ Idem, pp.14-15.
} 
cotidiano em cada um deles. Como são alegorias, apresentam uma identidade coletiva, representando não só a existência de um indivíduo, mas de uma classe, de um grupo religioso, de um status social, de uma manifestação cultural. Essa tipificação dos personagens salienta-se, inclusive, pela opção do autor em não nomear alguns deles, como o padre, padeiro, mulher do padeiro; o que acontece nas tragédias com os mensageiros, coros, amas.

Dos personagens da peça, o que mais se destaca quanto à representação popular é João Grilo, que se aproveita da avareza e da ambição dos ricos da cidade para enganá-los e conseguir o pão que lhe falta diariamente. Tal comportamento, na peça, é tolerado e aceito devido à falta de opção aos brasileiros e nordestinos que precisam driblar a miséria e a mesquinhez dos patrões. Tanto que, quando João Grilo morre e é julgado por Jesus, que na peça é chamado de Manuel, clama pela Compadecida que não o condena, afirmando que ele não tinha escolha para a sobrevivência. No final, Manuel, a pedido da mãe, acaba deixando João voltar à vida.

A COMPADECIDA: Intercedo por esses pobres que não têm ninguém por eles, meu filho. Não os condene. (p.174)

(...)

A COMPADECIDA: João foi pobre como nós, meu filho. Teve de suportar as maiores dificuldades, numa terra seca e pobre como a nossa. Não o condene, deixe João ir para o purgatório. (184)

(...)

A COMPADECIDA: Dê-lhe então outra oportunidade.

MANUEL: Como?

A COMPADECIDA: Deixe João voltar. (p.185)

(...)

JOÃO GRILO: Quer dizer que posso voltar?

MANUEL: Pode, João, vá com Deus. (p. 188-189)

Um personagem grego que também é conhecido pela astúcia e pela arte de enganar é Odisseu, herói grego que passou dez anos tentando retornar ao lar e que, depois de perder os amigos e a própria nau (canto XII), consegue chegar a seu destino graças a sua grande eloquência, capacidade de persuadir e de encontrar soluções para problemas que pareciam impossíveis de serem resolvidos. Assim como João Grilo, Odisseu tinha uma importante protetora, a deusa Atena. Entretanto diferentemente da Compadecida, que apenas intercede por João a fim de que não seja condenado e não morra, Atena age diretamente na empreitada de Odisseu, como no episódio em que o disfarça de mendigo para que não fosse reconhecido por seus inimigos (canto XIV).

Outro personagem conhecido pela meticulosidade e astúcia é Sileno e seus filhos sátiros. Como João Grilo e Odisseu, eles trapaceiam e mentem, porém 
com fins nada nobres, geralmente relacionados à adoração quase patológica que mantêm pelo vinho e por sexo, presentes do deus de cujo séquito fazem parte, Dioniso. Por mais que o comportamento de tais figuras seja inconveniente e ilícito para o cidadão ateniense, ele é risível e até aceito, pois representam "outra faceta inconfessável ao ser humano, a faceta anti-heroica mais elementar e natural"'. Os sátiros assemelham-se aos jovens aristocratas atenienses do século $\mathrm{V}$ a.C, quando se entregam à bebida e ao sexo nos banquetes ${ }^{4}$. Tal comportamento, dessa forma, torna-se desculpável por existir uma razão de ser, que é a entrega a Dioniso, assim como é aceitável a trapaça de João Grilo, pois ela é motivada pela necessidade de sobrevivência.

Logo os dois tipos de comportamento são demonstrações de condutas típicas de sua cultura: os sátiros são os jovens em honras a Dioniso em um banquete, enquanto a astúcia de João Grilo demonstra o típico "jeitinho" brasileiro. São condutas imorais, que se tentam ocultar, mas que fazem parte da cultura popular e que às vezes, mesmo que veladamente, são vistas com certo orgulho patriótico.

Assim como a alegoria a que se prestam as personagens nos mostram características culturais e cidadãs do país e da região a que pertence a peça, a estrutura e o enredo do Auto da Compadecida evidenciam traços da cultura e da realidade brasileiras, o que pode ser observado pela pluralidade de fontes e de estilos, o que remonta também à hibridez do drama satírico. $O$ fato de a peça constituir-se de um auto, com moralidade católica, mas um diabo vestido de couro é um traço disso. Outro aspecto relevante e que merece atenção é a presença do palhaço.

Podemos dizer que ele é um traço metalinguístico no texto e também é um dos responsáveis pela comicidade da peça, sendo um ligado ao outro, quando ele organiza, por exemplo, a passagem do segundo para o terceiro ato, como pode ser observado a seguir:

PALHAÇO (entrando) : Peço desculpas ao distinto público que teve de assistir a essa pequena carnificina, mas ela era necessária ao desenrolar da história. Agora a cena vai mudar um pouco. João, levante-se e ajude a mudar o cenário. Chicó! Chame os outros.

CHICÓ: Os defuntos também?

PALHAÇO: Também.

CHICÓ: Senhor Bispo, Senhor Padre, Senhor Padeiro! Aparecem todos.

PALHAÇO: É preciso mudar o cenário, para a cena do julgamento de vocês.

3 "La otra faceta inconfesable del ser humano, la faceta antiheroica más elemental y natural". Eire, Reflexiones sobre la lengua del drama satírico, p. 93.

${ }^{4}$ Griffith, Satyrs, citizens, and self-presentation, p. 174. 
Tragam o trono de Nosso Senhor! Agora a igreja vai servir de entrada para o céu e para o purgatório. $\mathrm{O}$ distinto público não se espante ao ver, nas cenas seguintes, dois demônios vestidos de vaqueiro, pois isso decorre de uma crença no sertão do Nordeste. Agora os mortos. Quem estava morto?

BISPO: Eu.

PALHAÇO: Deite-se ali.

PADRE: Eu também.

PALHAÇO: Deite-se junto dele. Quem mais?

JOÃO GRILO: Eu, o padeiro, a mulher, o sacristão, Severino e o cabra.

PALHAÇO: Deitem-se todos e morram.

JOÃO GRILO: Um momento.

PALHAÇO: Homem, morra, que o espetáculo precisa continuar! (p. 134-136)

Da mesma forma, o coro de sátiros, no drama satírico, dança e canta de forma cômica, como relata Barbosa a seguir:

As danças báquicas da comédia e drama satírico figuram bailarinos bêbados possuídos pelo deus (é o caso das ninfas, sátiros, Pã e silenos). De acordo com Platão, suas posturas imitam ações que deveriam ser encomendadas para os escravos e estrangeiros (cf. Leis, 7, 816 e). Os espectadores, vendo o feio, saberiam reproduzir o seu oposto. (...) O coro de Dioniso, mais maduro e ciente, deve saber produzir - com seus gestos - tanto a nobreza e grandeza exigida na emméleia, dança da tragédia, quanto a vulgaridade e baixeza da síkinnis e do kórdax, danças do drama satírico e da comédia respectivamente. Elas são úteis para fazer conhecer o ridículo e grotesco (Barbosa, 2008, p. 5).

Ambas as peças apresentam, como se pode observar, personagens cômicos por natureza, além de a peça, seja ela o Auto da Compadecida ou qualquer drama satírico, também apresentar, em suas cenas, situações risíveis. Isso pode ser evidenciado nas trapalhadas dos protagonistas do auto ao enganarem os líderes religiosos da cidade convencendo-os a enterrar um cachorro (Primeiro ato), ou nos dramas satíricos, como o Ciclope, quando Sileno tenta enganar o ciclope Polifemo e Ulisses, arriscando convencer o primeiro de que estava protegendo os seus pertences da tentativa de roubo do herói grego.

Assim, é possível perceber que a peça Auto da Compadecida, de Ariano Suassuna, apresenta traços moralizantes e cômicos que remetem ao teatro grego do século $\mathrm{V}$, sobretudo à tragédia e ao drama satírico. $\mathrm{O}$ enredo e as personagens evidenciam ambas as características tanto na obra contemporânea como na antiga, evidenciando, dessa forma, os resquícios e herança clássica na cultura, no teatro e até mesmo na tradição brasileira. 